\title{
新規トロンボキサン $\mathbf{A}_{2}$ 受容体拮抗薬 $(\mathbf{S}-1452)$ の ラットにおける代謝物の同定
}

\author{
溝尻 顕爾, 乗鞍良, 吉森 丈夫, 中西真智子, 岩谷 宏治 \\ 塩野義製薬研究所神崎川分室 $\overline{7} 561$ 豊中市二葉町3-1-1
}

照井 涁弘, 菊池 純子, 中川 有造

塩野義製薬研究所 $\overline{7} 553$ 大阪市福島区䉆洲5-12-4

Key words : S-1452, (+)-S-145, Rat, Metabolism, Urine, Bile, Plasma, ${ }^{1} \mathrm{H}-\mathrm{NMR}, \mathrm{GC} / \mathrm{MS}$, LSIMS

\section{Identification of Metabolites of a New Thromboxane $A_{2}$ Receptor Antagonist, S-1452, in Rats}

Kenji MizoJiri, Ryo Norikura, Takeo Yoshimori, Machiko NAKANISHI, and Kouji Iwatani

Kanzakigawa Laboratory, Shionogi Research Laboratories, Shionogi \& Co., Ltd., 3-1-1, Futaba-cho, Toyonaka-shi, Osaka 561, Japan

Yoshihiro Terui, Junko KIKUchi, and Yuzo NAKagawa

Shionogi Research Laboratories, Shionogi \& Co., Ltd., 5-12-4, Sagisu, Fukushima-ku, Osaka 553, Japan

\section{Summary}

The metabolism of S-1452, calcium $(5 Z)-7-[(1 R, 2 S, 3 S, 4 S)-3-$ phenylsulfonylaminobicyclo [2. 2.1]hept $-2-\mathrm{yl}]-5$-heptenoate hydrate, a new $\mathrm{TXA}_{2}$ receptor antagonist, in rats was studied. Twelve unconjugated metabolites including the unchanged free acid of $\mathrm{S}-1452,(+)-\mathrm{S}-145$, and three $\alpha$-chain-shortended metabolites, bisnor-, dihydrobisnor- and tetranor- $(+)-\mathrm{S}-145$, and four pairs of their regioisomeric metabolites, hydroxylated at the 5- or 6-position of the bicyclo ring, were isolated from plasma after oral administration of ${ }^{14} \mathrm{C}-\mathrm{S}-1452$ or unlabelled S-1452. Two of the hydroxylated metabolites, 5- $\mathrm{OH}$-tetranor- and 6-OH-tetranor- $\left.{ }^{-}+\right)-\mathrm{S}-145$, were also isolated from urine. Furthermore, four taurine-conjugated metabolites, (+) $-\mathrm{S}-145$, bisnor-(+)-S-145, dihydrobisnor-(+)-S-145 and tetranor-(+)-S-145 taurine, were isolated from bile. The structures of these metabolites were identified by means of GC/MS, LSIMS and ${ }^{1} \mathrm{H}-\mathrm{NMR}$ analyses in comparison with their synthesized reference compounds. The stereochemistry of $6-\mathrm{OH}^{-}(+)-\mathrm{S}-145$, the exo configuration of its hydroxy group, was confirmed by comparison of its retention time on HPLC with those of endo and exo reference standards. Other hydroxylated metabolites also were considered to be of the exo configulation. Tentative metabolic pathways in rats are presented and discussed. 


\section{緒 言}

Calcium (5Z)-7-[(1R, 2S, 3S, 4S)-3-phenylsulfonylaminobicyclo [2. 2.1] hept $-2-\mathrm{yl}]-5-$ heptenoate hydrate $(\mathrm{S}-1452)$ は, 強力な $\mathrm{TXA}_{2}$ 受容体拮抗作用を有する (+) -S-145 $5^{1 \text { 3) }}$ の安定 な $\mathrm{Ca}$ 塩として当研究所で合成され ${ }^{4)}$, 経口剂と して有効な気管支喘息および血栓塞栓性疾患の治 療薬5 7) として開発中の薬物である.

本報では，S-1452のラットに打壮代謝物を 血漿, 尿拉よび胆汁より単離同定した結果につい て報告する。

\section{実験材料および方法}

\section{1. 投与化合物および試薬}

非標識S $-1452^{4)},{ }^{14} \mathrm{C}$ 標識S-1452 ${ }^{8)}\left({ }^{14} \mathrm{C}-\mathrm{S}-1452\right)$, 非標識 $\mathrm{S}-145^{2)}$ (S-1452遊離酸のラセミ体) およ び14 $\mathrm{C}$ 標識 $\mathrm{S}-145\left({ }^{14} \mathrm{C}-\mathrm{S}-145\right)$ は当研究所で合成 された、 ${ }^{14} \mathrm{C}-\mathrm{S}-1452$ の比放射能は757 $\mathrm{kBq} / \mathrm{mg}$, 放射化学的純度は $94.3 \%,{ }^{14} \mathrm{C}-\mathrm{S}-145$ の比放射能 は1. $17 \mathrm{MBq} / \mathrm{mg}$, 放射化学的純度は97\%以上で あった. ${ }^{14} \mathrm{C}-\mathrm{S}-1452$ の構造式を Fig. 1 に示す.
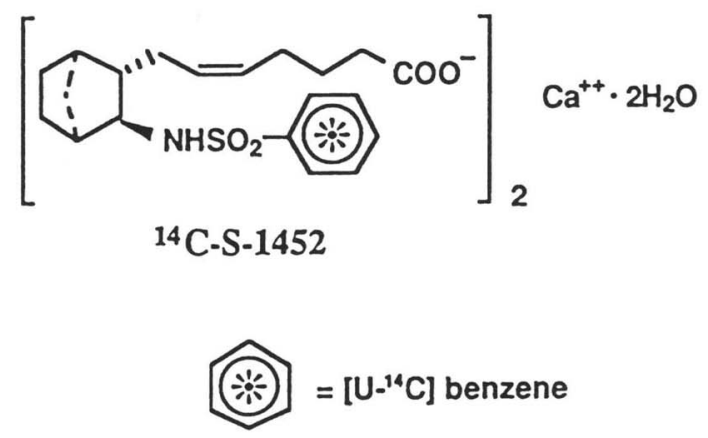

Fig. 1 Chemical stucture of ${ }^{14} \mathrm{C}-\mathrm{S}-1452$

誘導体試薬 trimethylsilyldiazomethane (TMSD) はナカライテスクょり, N, O-bis (trimethylsilyl) trifluoroacetamide (BSTFA) はジーェルサイエンスより購入した. $\beta$-Glucuronidase は Type-1(東京蔵器) を用いた。 その 他の試薬, 溶媒は市販の特級品もしくは HPLC 用を用いた。

\section{2. 合成標品}

当研究所で合成された以下の標品9）を用いた。 それらの化学名を以下に示し，構造式を Fig. 2 に示す.

(1) (+)-S-145; (5Z)-7-[(1R, 2S, 3S, 4S)-3 -phenylsulfonylaminobicyclo[2.2.1]-hept-2yl]-5-heptenoic acid.

(2) Bisnor-(+)-S-145; (3Z) $-5-[(1 R, 2 S, 3$ $S$, 4S)-3-phenylsulfonyla minobicyclo-[2. 2 . 1]hept-2-yl]-3-pentenoic acid.

(3) Dihydrobisnor-(+)-S-145; $-[(1 R, 2 S$, $3 S, 4 S)-3-$ phenylsulfonylaminobicyclo[2. 2 . 1]hept $-2-y 1]$ pentanoic acid.

(4) Tetranor-(+)-S-145;3-[(1R, 2S, 3S, $4 S)$-3- phenylsulfonylaminobicyclo [2.2.1] hept-2-yl] propionic acid.

(5) 5-OH-(+)-S-145; (5Z)-7-[(1S, 2S, 3R, $4 S$, 5R)-5-hydroxy-3-phenylsulfonyla minobicyclo[2. 2. 1]hept-2-yl]-5-pentenoic acid.

(6) 5-OH-Bisnor-(+)-S-145; (3Z)-5-[(1S, $2 S, 3 R, 4 S, 5 R)-5$-hydroxy-3-phenylsulfonylaminobicyclo[2. 2.1]hept-2-yl]-3-pentenoic acid.

(7) 5-OH-Dihydrobisnor-(+)-S-145; 5-[(1 $S, 2 S, 3 R, 4 S, 5 R)-5$-hydroxy-3-phenylsulfonylaminobicyclo[2.2.1]hept-2-yl]pentanoic acid.

(8) 5-OH-Tetranor-(+)-S-145;3-[(1S, 2S, $3 R, 4 S, 5 R)-5$-hydroxy-3-phenylsulfonylaminobicyclo[2.2.1]hept-2-yl]propionic acid. (9) 6- $\mathbf{O H}-(+)-\mathbf{S}-145 ;(5 Z)-7-[(1 R, 2 S, 3 S$, $4 R$, 6S)-6-hydroxy-3-phenylsulfonylaminobicyclo[2. 2. 1] hept-2-yl]-5-heptenoic acid. (10) 6-OH- $-(+)-\mathbf{S}-145$ (endo) ; $(5 Z)-7-[(1 R$, $2 S, 3 S, 4 R, 6 R)-6$-hydroxy-3-phenylsulfonylaminobicyclo[2. 2.1]hept-2-yl]-5-heptenoic acid.

(11) 6-OH-Bisnor-(+)-S-145; (3Z) $-5-[(1 R$, $2 S, 3 S, 4 R, 6 S)-6$-hydroxy-3-phenylsulfonylaminobicyclo[2.2.1]hept-2-yl]-3-pentenoic acid.

(12) 6-OH-Dihydrobisnor-(+)-S-145; 5-[(1 $R, 2 S, 3 S, 4 R, 6 S)-6$-hydroxy-3-phenylsul- 


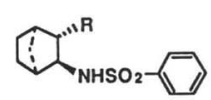
(1) (+)-S-145
(2) Bisnor-(+)-S-145
(3) Dihydrobisnor-(+)-S-145
(4) Tetranor-(+)-S-145

(14) (+)-S-145 taurine

(15) Bisnor-(+)-S-145 taurine

(16) Dihydrobisnor-(+)-S-145 taurine

(17) Tetranor-(+)-S-145 taurine

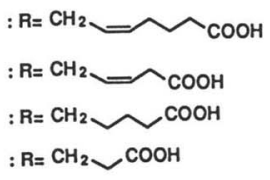

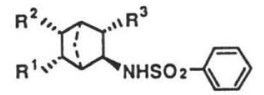

(5) $5 \cdot \mathrm{OH} \cdot(+) \cdot \mathrm{S}-145$

(6) $5 \cdot \mathrm{OH} \cdot$ Bisnor-(+)-S-145

: $\mathrm{R}^{1}=\mathrm{OH}, \mathrm{R}^{2}=\mathrm{H}, \mathrm{R}^{3}=\mathrm{CH}_{2} \longrightarrow \mathrm{COOH}$

COOH

(7) 5-OH-Dihydrobisnor-(+)-S.145: $\mathrm{R}^{1}=\mathrm{OH}, \mathrm{R}^{2}=\mathrm{H}, \mathrm{R}^{3}=\mathrm{CH}_{2} \sim \mathrm{COOH}$

(8) 5-OH-Tetranor-(+)-S-145 : $\mathrm{R}^{1}=\mathrm{OH}, \mathrm{R}^{2}=\mathrm{H}, \mathrm{R}^{3}=\mathrm{CH}_{2} \sim \mathrm{COOH}$

(9) \%-OH-(+)-S-145

(11) 6-OH-Bisnor-(+)-S-145

$: \mathrm{R}^{1}=\mathrm{H}, \mathrm{R}^{2}=\mathrm{OH}, \mathrm{R}^{3}=\mathrm{CH}_{2}$

(12) 6-OH-Dihydrobisnor-(+)-S-145: $\mathrm{R}^{1}=\mathrm{H}, \mathrm{R}^{2}=\mathrm{OH}, \mathrm{R}^{3}=\mathrm{CH}_{2} \sim \mathrm{COOH}$

(13) 6.0H-Tetranor-(+)-S-145

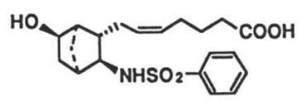

(10) 6-OH-(+)-S-145 (endo )

Fig. 2 Chemical stuctures of authentic compounds

fonylaminobicyclo[2.2.1]hept-2-yl]pentanoic acid.

(13) 6-OH-Tetranor-(+)-S-145; 3-[(1R, 2S, $3 S, 4 R, 6 S)$-6-hydroxy-3-phenylsulfonylaminobicyclo[2.2.1]hept-2-yl]propionic acid. (14) (+)-S-145 taurine ; $N-[(5 Z)-7-[(1 R, 2$ $S, 3 S, 4 S)-3-$ phenylsulfonylaminobicyclo[2. 2. 1]hept-2-yl]-5-heptenoyl] taurine.

(15) Bisnor- $-(+)-\mathbf{S}-145$ taurine ; $N-[(3 Z)-7-$ $[(1 R, 2 S, 3 S, 4 S)-3-$ phenylsulfonyla minobicyclo[2. 2. 1]hept-2-yl]-3-pentenoyl]taurine.

(16) Dihydrobisnor-(+)-S-145 taurine ; $N$ $[5-[(1 R, 2 S, 3 S, 4 S)-3-$ phenylsulfonylaminobicyclo[2.2.1]hept-2-yl] pentanoyl]taurine. (17) Tetranor-(+)-S-145 taurine ; $N-[3-[(1$ $R, 2 S, 3 S, 4 S)-3-$ phenylsulfonyla minobicyclo [2.2.1]hept-2-yl] propionyl] taurine.

\section{3. 実験動物}

Sprague-Dawley 系雄性ラット（日本クレ ア）を 2 週間以上予備飼育し，9 10週齢（体 重：280〜300 g ） で使用した。購入後のラットは 水抄よび固形飼料（CA-1，日本クレア）を自由 に摂取させ，温度 $23 \pm 2{ }^{\circ} \mathrm{C}$ ，湿度 $55 \pm 10 \%$ ，照明 時間12時間の条件下で飼育した，血漿あるいは尿
中代謝物に関する投与では 24 時間絶食して, 胆汁 中代謝物に関する投与では絶食せずに用いた。

\section{4. 投与液の調製，投与方法および試料採取}

血漿あるいは尿中代謝物検索のために ${ }^{14} \mathrm{C}-\mathrm{S}-$ 1452 を $5 \mathrm{mg} / 2 \mathrm{ml} / \mathrm{kg}$ で，代謝物分離のために 非標識S-1452を $100 \mathrm{mg} / 2 \mathrm{ml} / \mathrm{kg}$ で，いずれも $0.5 \%$ ×ルセルロース懸濁液で経口投与した. 血漿採取用ラットは投与後45分にエーテル麻酔し, 腹部下行大動脈から採血して，遠心分離により血 墏を得た。尿採取用ラットは投与後ボールマン ケージ（KN-326型，夏目製作所）に固定し， 24 時間まで尿を採取した。胆汁中代謝物検索のため に ${ }^{14} \mathrm{C}-\mathrm{S}-145 を 10 \mathrm{mg} / 2 \mathrm{~m} l / \mathrm{kg}$ で，代謝物分離の ために非標識S-145を $100 \mathrm{mg} / 2 \mathrm{ml} / \mathrm{kg}$ で，いず れも $0.5 \%$ チルセルロース懸濁液で経口投与し， 投与後 8 時間まで, 酢酸緩衝液 ( た容器中に胆汁を採取した。このときのラットに は, あらかじめエーテル麻酔下で胆管カニュレー ションを施したのらボールマンケージに固定し， 麻酔覚醒後 $2 \sim 3$ 時間に投与した。

\section{5. 代謝物の検索}

1）血漿中代謝物

${ }^{14} \mathrm{C}-\mathrm{S}-1452$ を投与後採取した血漿に $0.1 \mathrm{~N}$ 塩酸 
を添加して pH 3 に調整し， 4 倍量の n-ブチル クロライドあるいは酢酸エチルで 4 回抽出した. これらの抽出溶媒を減圧留去し, それぞれの乾固 物を少量のメタノールに溶解して TLC を行っ た. プレートはシリカゲル $60 \mathrm{~F}_{254}$ (No. 5715,

Merck）を用い， nーブチルクロライドで抽出し た低極性代謝物は, $\mathrm{n}$-ペンタンノクロロホル ム/酢酸（6:3:1, V/V/V) で，酢酸エチル で抽出した高極性代謝物はクロロホルム/メタ ノール/酢酸（7:1:1，V/V/V) で展開した。 展開後のプレートをX線フィルム（医療用 $\mathrm{RX}$, 富士写真フィルム）に暴露させてオートラジオグ ラム（TLC-ARG）を作成し, 標品の $R f$ 值と 比較することにより代謝物を検索した。

\section{2）尿中代謝物}

${ }^{14} \mathrm{C}-\mathrm{S}-1452$ を投与後の尿について，血漿の場 合と同様の方法で酢酸エチル抽出を行い, TLC 分離および TLC-ARG により代謝物を検索し た.

\section{3）胆汁中代謝物}

${ }^{14} \mathrm{C}-\mathrm{S}-145$ を投与後 8 時間までの胆汁について, 次のように代謝物を分離した。胆汁 $1.5 \mathrm{~m} l を 0.5$ M酷酸緩衝液で pH5.0亿調整し, $\beta$-glucuronidase $200 \mu l$ を加光て $37^{\circ} \mathrm{C} て ゙ 18$ 時間インキュベー トした.インキュベート終了後 $1 \mathrm{~N}$ 塩酸で $\mathrm{pH} 3$ に調整し, 酢酸エチル $6 \mathrm{ml}$ で 2 回抽出を行い, 酶酸エチル可溶性代謝物を除去した。水相を酸性 処理した SEP-PAK ( $\mathrm{C}_{18}$, Waters) に添加し, $0.02 \mathrm{~N}$ 塩酸 $10 \mathrm{~m} l$ で洗浄後, メタノール $5 \mathrm{ml}$ で 溶出し, 溶出画分を乾固後 TLC を行った. プ レートはシリカゲル $60 \mathrm{~F}_{254}$ を用い, クロロホル ムノメタノール/水/酢酸 $(13: 10: 3: 1, \mathrm{~V} /$ $\mathrm{V} / \mathrm{V} / \mathrm{V})$ で展開した。展開後のプレートをX線 フィルムに暴露させて TLC-ARG を作成した. TLC-ARG を指標にして代謝物の展開部分を 4 分画し, 各分画をかきとり, メタノールで抽出後 HPLC で分離した. HPLC では，ポンプは Waters $6000 \mathrm{~A}$ を, 検出器は UVIDEC-100-II

$(220 \mathrm{~nm}$ ，日本分光）を使用した。 カラムは Nucleosil $5 \mathrm{C}_{18} 4.6 \phi \mathrm{mm} \times 150 \mathrm{~mm}$ (ケムコ) を 用い, アセトニトリルノメタノール/リン酸緩衝 液 $(50 \mathrm{mM}, \mathrm{pH} 3.0)(200: 50: 700, \mathrm{~V} / \mathrm{V} / \mathrm{V})$ の移動相を $1.5 \mathrm{ml} / \mathrm{min}$ の流速で溶出した.

\section{6. 代謝物の単離}

\section{1）血漿および尿中代謝物}

非標識S-1452を投与後の血漿について，上記 と同様の方法で $\mathrm{n}$-ブチルクロライドあるいは酢 酸エチルで抽出後 TLC 分離を行った，展開後 の代謝物部分のシリカゲルをかきとり，メタノー ルで抽出した. メタノール抽出液を濃縮し, HPLC により $\mathrm{n}$ ーブチルクロライド抽出物から $\mathrm{M}-1$, M-2, M-3，M-4を，酢酸エチル抽出物から M-5, M-6, M-7, M-8, M-9, M-10, M-11, M-12 を分取した。 また，非標識S-1452投与後の尿に ついて酢酸エチル抽出を行い, 同様の方法により M-8およびM-12を分取した. HPLC は5.3）に 記載した装置特よびカラムで行った。ただし，移 動相はアセトニトリル/メタノール/水/酢酸を 用い, 低極性代謝物の分離では $(30: 200: 300$ : $1, \mathrm{~V} / \mathrm{V} / \mathrm{V} / \mathrm{V})$ で, 高極性代謝物の分離では (220:130:650:1, V/V/V/V) で使用した. 流速はいずれも $1.5 \mathrm{ml} / \mathrm{min}$ とした.

\section{2）胆汁中代謝物}

非標識S-145を投与後 8 時間までの胆汁につい て，上記と同様の方法で処理して水溶性代謝物を 単離した. HPLC による精製は, セミ分取カラ ムによる粗分取と, 分析カラムによる精製の 2 段 階で行った．いずれの HPLC においても前記 と同じ装置を用いたが，粗分取ではカラムはNucleosil $10 \mathrm{C}_{18} 7.5 \phi \mathrm{mm} \times 300 \mathrm{~mm}$ (ケムコ) を用 いて, アセトニトリル/メタノールリン酸緩衝 液 $(50 \mathrm{mM}$, pH3.0) (300:200：700, V/V/ V) を流速 $1.5 \mathrm{~m} l / \mathrm{min}$ で溶出し, 精製ではカラ $\triangle$ Nucleosil $5 \mathrm{C}_{18} 4.6 \phi \mathrm{mm} \times 150 \mathrm{~mm}$ (ケム コ）を用いて，上記移動相を $\mathrm{M}-\mathrm{A} の$ 分離では (200:50:450, V/V/V) の組成で，M-Bでは (200:50:500, V/V/V)で, M-Cでは (200: $50: 600, \mathrm{~V} / \mathrm{V} / \mathrm{V})$ で, M-Dでは $(200: 50$ : $700, \mathrm{~V} / \mathrm{V} / \mathrm{V})$ で, いずれも $1.5 \mathrm{~m} l / \mathrm{min}$ で溶出 した.

\section{MS 分析}

血漿より単離した低極性代謝物M-1， M-2, M -3，M-4，执よびその標品は TMSD によりメ チルエステル誘導体とした。 血漿と尿より分取し た高極性代謝物M-5, M-6, M-7, M-8, M-9, 
M-10, M-11，M-12, およびその標品はTMSD でメチルェステル誘導化後さらに BSTFA で TMS 化を行った. これらの誘導化後の代謝物に ついて, GC/MS(EI) 分析を行った。装置はGC 5890A (Hewlett Packard) を接続した Mass Selective Detector 5970 (Hewlett Packard) を使用した，カラムは Ultra-1 $(12 \mathrm{~m} \times 0.2 \phi$ mm, i.d., Hewlett Packard) を用い，キャリ アーガス（He）流量を $1.5 \mathrm{~kg} / \mathrm{cm}^{2}$ とし、イオン 化電圧 $70 \mathrm{eV}$ で測定した.

胆汁中代謝物 $M-A, M-B, M-C, M-D$, 叔 よびその標品については LSIMS 分析を行った. 装置は日立M-8022型 SIMS イオン源を装備し た日立M-68型質量分析計（M-80型と同等品）を 使用し，正イオン測定，負イオン測定ともに一次 イオンに $\mathrm{Xe}^{+}$, 一次加速電圧 $9 \mathrm{kV}$, 二次加速電 圧 $3 \mathrm{kV}$ に設定した，測定はメタノールに溶解し た約 $5 \mu \mathrm{g}$ 相当量の試料を LSIMS 用ターゲット 板 $(\mathrm{Ag})$ 上に叙布したマトリックス剤（約 $2 \mu l$
のグリセロール） と混合し， $1 \mu l$ の0.1N塩酸を 添加して行った.

\section{NMR 分析}

${ }^{1} \mathrm{H}-\mathrm{NMR}$ スペクトルは XL-400核磁気共鳴装 置（Varian）を用いて，水素核を $400 \mathrm{MHz}$ で観 測した. 試料を $\mathrm{CD}_{3} \mathrm{OD}$ に約 $0.1 \mathrm{mg} / 0.5 \mathrm{~m} l$ に 溶解し, 内部標準として TMS を添加して室温 で測定した.

\section{結 果}

1. 血漿, 尿および胆汁中代謝物の HPLCプロファイル

S-1452を経口投与後45分の血漿，および24時 間の尿より抽出した代謝物についての HPLC プ ロファイルを Fig. 3 扎よび Fig. 4 に，ラセミ 体のS-145を経口投与後 8 時間の胆汁を $\beta-$ glucuronidase で処理後抽出した代謝物の HPLC プ ロファイルを Fig. 5 に示す。各クロマトグラム

\section{A. n-Butylchloride extracts}

\section{B. Ethyl acetate extracts}
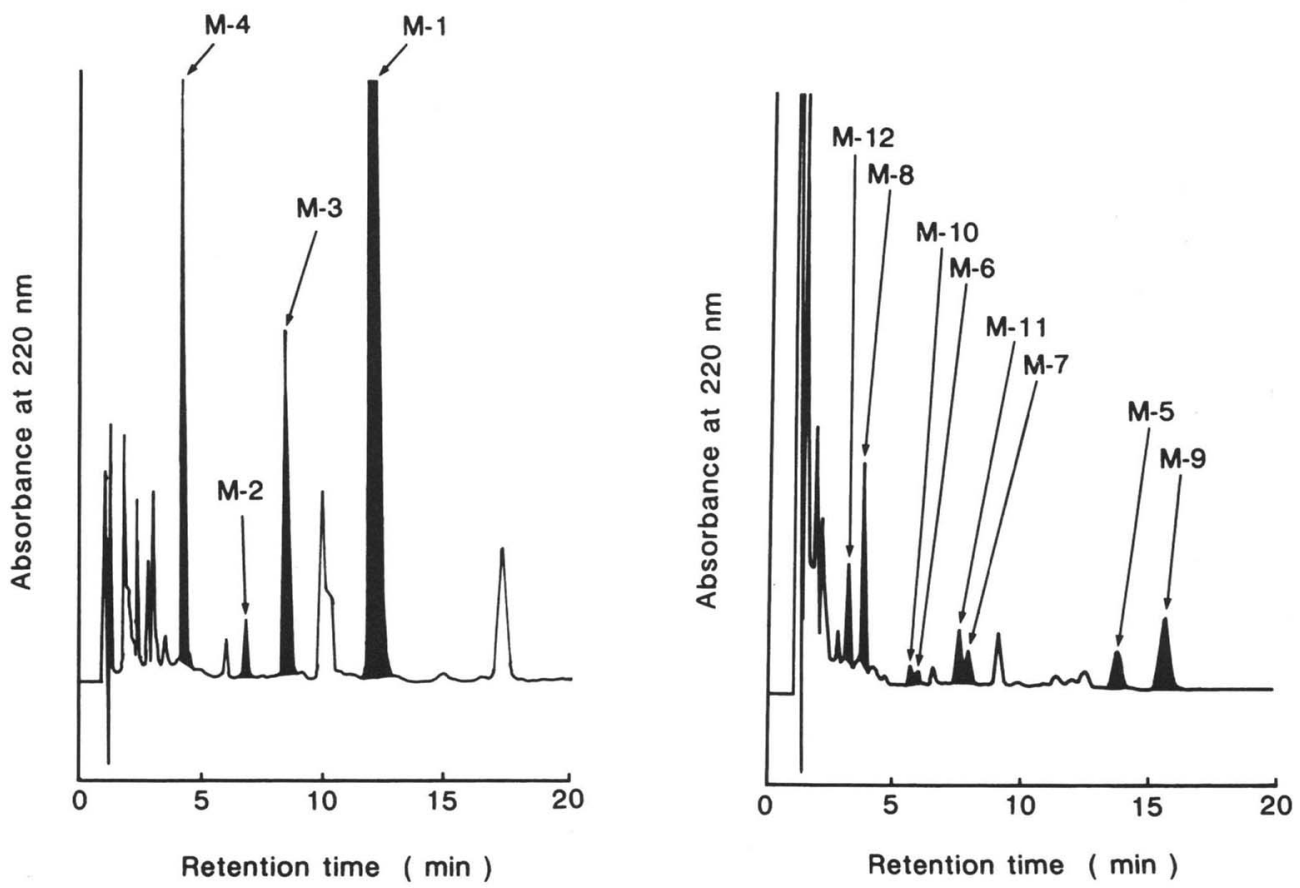

Fig. 3 High performance liquid chromatograms of $n$-butylchloride and ethyl acetate extracts of rat plasma after oral administration of S-1452 


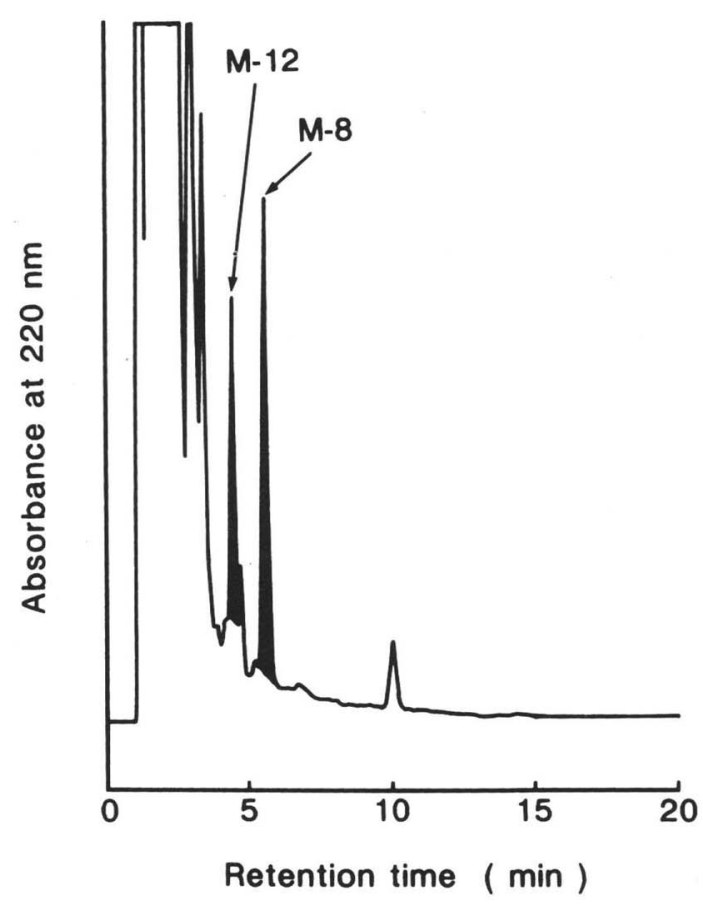

Fig. 4 High performance liquid chromatogram of ethyl acetate extracts of rat urine after oral administration of S-1452

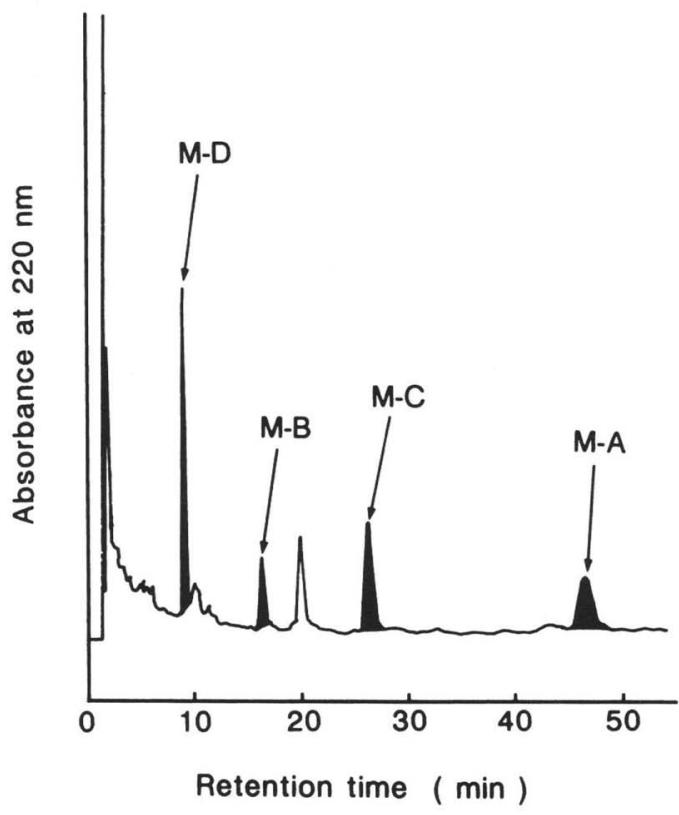

Fig. 5 High performance liquid chromatogram of bile extracts after oral administration of S-145 to rats
で黒色で表示したピークは，別途に ${ }^{14} \mathrm{C}-\mathrm{S}-1452$ あるいは ${ }^{14} \mathrm{C}-\mathrm{S}-145$ を投与した試料を HPLC 分 取し，放射能を確認した代謝物である。

血漿では, n-ブチルクロライドにより 4 種の 低極性代謝物M-1，M-2，M-3，M-4が抽出され， これらは HPLC で良好に分離された（Fig. 3

A). 酢酸エチルでは 4 種の低極性代謝物以外に 8 種の高極性代謝物が抽出され，それらは展開時 間が近接した 4 組のペアーピークとして分離され た (Fig. $3 \mathrm{~B})$.

尿中の代謝物は， ${ }^{14} \mathrm{C}-\mathrm{S}-1452$ 投与試料を用い た検討によると， $\mathrm{n}$ ーブチルクロライドでは抽出 されず，大部分が酢酸エチルで抽出され，その中 の主な代謝物はM-8， M-12の 2 種類であった

(Fig. 4 ).

胆汁中には $\beta$-glucuronidase で加水分解され ず，さらに酢酸エチルでも抽出されない代謝物と してM-A，M-B， M-C およびM-Dの 4 種が検 出され, これらは HPLC で良好に分離された

(Fig. 5 ).

\section{2. 血漿中代謝物の構造 \\ 1）低極性代謝物}

血漿中より単離した低極性代謝物 $\mathrm{M}-1, \mathrm{M}-2$, M-3およびM-4のメチルェステル誘導体の GC/ MS スペクトルを Fig. 6 に示す.

M-1のメチルェステル誘導体は $\mathrm{m} / \mathrm{z} 391$ に $[\mathrm{M}]^{+}$・が認められ，開裂イオンとして $[\mathrm{M}-$ $\left.\mathrm{OCH}_{3}\right]^{+}(\mathrm{m} / \mathrm{z} 360),\left[\mathrm{M}-\mathrm{SO}_{2} \mathrm{Ph}\right]^{+}(\mathrm{m} / \mathrm{z} 250)$, $\left[\mathrm{M}-\left(\mathrm{SO}_{2} \mathrm{Ph}+\mathrm{OCH}_{3}+\mathrm{H}\right)\right]^{+}(\mathrm{m} / \mathrm{z} 218)$ および $\left[\mathrm{SO}_{2} \mathrm{Ph}\right]^{+}(\mathrm{m} / \mathrm{z} 141)$ がみられた. これらのス ペクトルは, $(+)-\mathrm{S}-145$ 標品のメチルェステル 誘導体のスペクトルと一致し，両者は HPLCの 保持時間も一致することより, M-1は未変化体の （+）-S-145であると決定された。

M-2，M-3，M-4の×チルエステル誘導体では, いずれも分子イオンピークはみられなかったが, $\left[\mathrm{M}-\mathrm{OCH}_{3}\right]^{+}, \quad\left[\mathrm{M}-\mathrm{SO}_{2} \mathrm{Ph}\right]^{+}, \quad\left[\mathrm{M}-\left(\mathrm{SO}_{2} \mathrm{Ph}+\right.\right.$ $\left.\left.\mathrm{OCH}_{3}+\mathrm{H}\right)\right]^{+}$に相当するフラグメントイオン ピークがM-2では $\mathrm{m} / \mathrm{z}$ 332, 222, 190 に, M-3 では $\mathrm{m} / \mathrm{z} 334,224,192$ に, M-4では $\mathrm{m} / \mathrm{z} 306$, 196，164にそれぞれ認められた. さらに， m/z 141はいずれの代謝物にもみられ, $\mathrm{SO}_{2} \mathrm{Ph}$ の存 


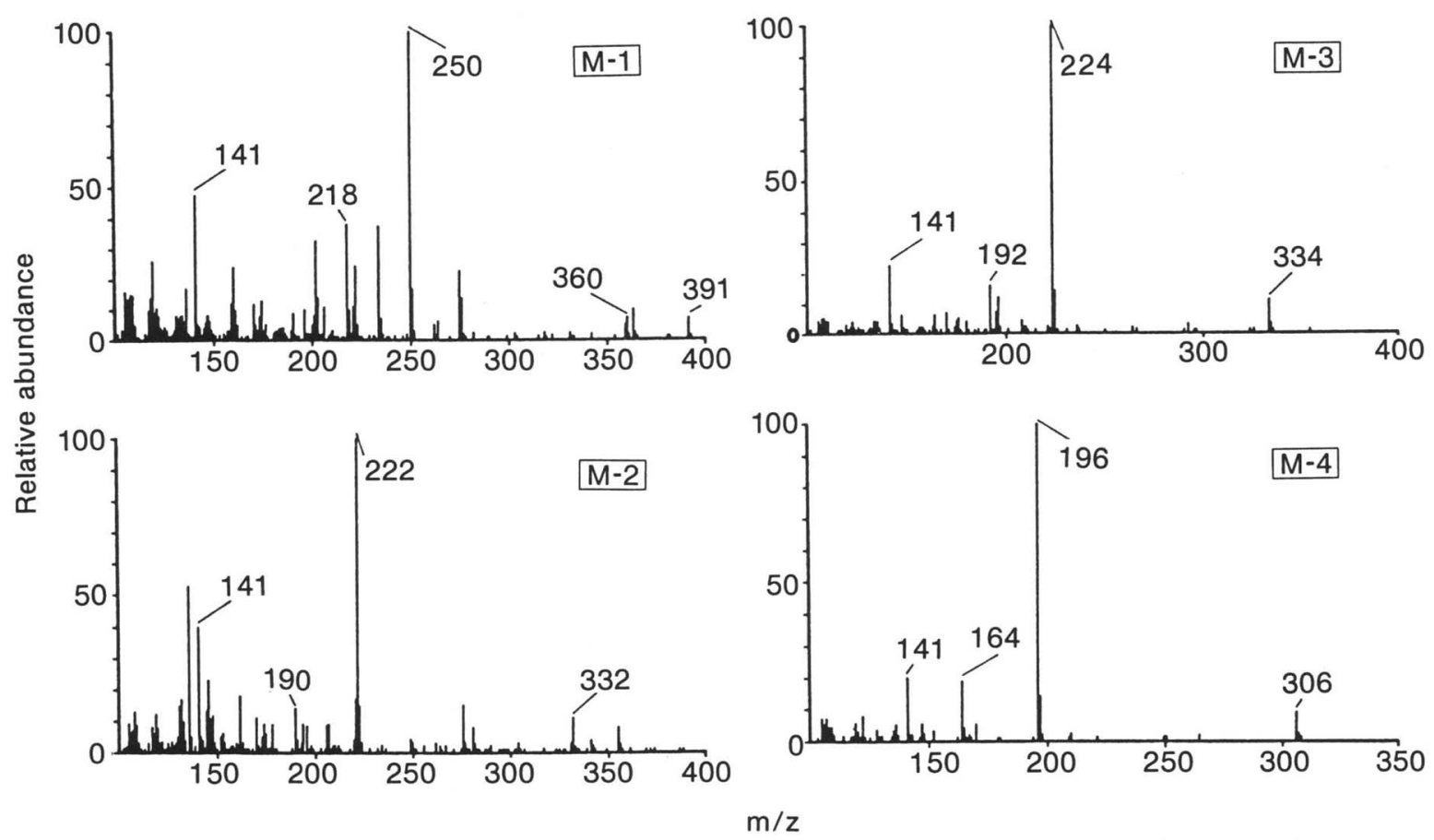

Fig. 6 EI mass spectra of the methyl ester derivatives of non-polar metabolites $(\mathrm{M}-1 \sim \mathrm{M}-4)$ isolated from rat plasma after oral administration of S-1452

在が示された。 これらのスペクトルより，M-2は (+)-S-145の $\alpha$-側鎖が $\beta$-酸化を受けた bisnor $-(+)-\mathrm{S}-145, \quad \mathrm{M}-3$ は bisnor-(+) $-\mathrm{S}-145$ の $\alpha$ 側鎖が飽和した dihydrobisnor- $(+)-\mathrm{S}-145$,

M-4は (+)-S-145の $\alpha$-側鎖が 2 回の $\beta$-酸化を 受けた tetranor-(+)-S-145であることが予測 された。 これらはそれぞれの標品と GC/MS ス ペクトル拈よび HPLC の保持時間が一致する ことよりその構造を決定した。

\section{2）高極性代謝物}

血漿中より単離した高極性代謝物M-5，M-6, M-7, M-8, M-9, M-10, M-11およびM-12の メチルェステル-TMS 誘導体の $\mathrm{GC} / \mathrm{MS}$ スペ クトルを Fig. 7 に示す.

8 種類の高極性代謝物のうちM-5については分 子イオンピーク $(\mathrm{m} / \mathrm{z} 479)$ が認められたが，そ の他の代謝物では観察されなかった，M-6を除く 7 種代謝物とも TMS 基よりメチル基 1 個が脱 離した $\left[\mathrm{M}-\mathrm{CH}_{3}\right]^{+}$がそれぞれ $\mathrm{m} / \mathrm{z} 465$ (M-5), 438 (M-7), 410 (M-8), 464 (M-9), 436 (M10), $438(\mathrm{M}-11), 410(\mathrm{M}-12)$ に観察された. そのほか 8 種の代謝物に共通して $\left[\mathrm{M}-\mathrm{SO}_{2} \mathrm{Ph}\right]^{+}$
(順に $\mathrm{m} / \mathrm{z} 338 ， 310 ， 312 ， 284 ， 338 ， 310 ， 312$, 284) と, $\left[\mathrm{SO}_{2} \mathrm{Ph}\right]^{+}(\mathrm{m} / \mathrm{z} 141)$ がみられた. M-5, M-7, M-8では, [M-TMSOH $]^{+}$(順に $\mathrm{m} / \mathrm{z} 389,363,335)$ と $\left[\mathrm{M}-\left(\mathrm{SO}_{2} \mathrm{Ph}+\mathrm{TMSOH}\right)\right]^{+}$ (順に $\mathrm{m} / \mathrm{z} 248,222,194)$ がみられた. 一方, M-9, M-10, M-11, M-12では, m/z 155が いずれも基準ピークとして認められたが，[M$\left.\left(\mathrm{SO}_{2} \mathrm{Ph}+\mathrm{TMSOH}\right)\right]^{+}$はみられなかった。 これ ら代謝物は (+)-S-145, bisnor-(+)-S-145, dihydrobisnor $-(+)-\mathrm{S}-145$ および tetranor(+)-S-145の，それぞれビシクロ環 5 位（M-9 〜 M-12） あるいは 6 位（M-5〜M-8）水酸化体 標品と GC/MS スペクトル，および HPLC 保 持時間が一致することよりその構造を決定した. ただし，M-6は夾雑ピークが多く鮮明なマススペ クトルを得ることがでさなかったが，予想標品 のスペクトルと $\left[\mathrm{SO}_{2} \mathrm{Ph}\right]^{+}(\mathrm{m} / \mathrm{z} 141),\left[\mathrm{M}^{-}\right.$ $\left.\left(\mathrm{SO}_{2} \mathrm{Ph}+\mathrm{TMSOH}\right)\right]^{+}(\mathrm{m} / \mathrm{z} 220),\left[\mathrm{M}-\mathrm{SO}_{2} \mathrm{Ph}\right]^{+}$ (m/z 310)などが一致すること，および HPLC の保持時間が一致することから，6-OH-bisnor(+)-S-145であると決定した。

\section{3）高極性代謝物の水酸基の配位}



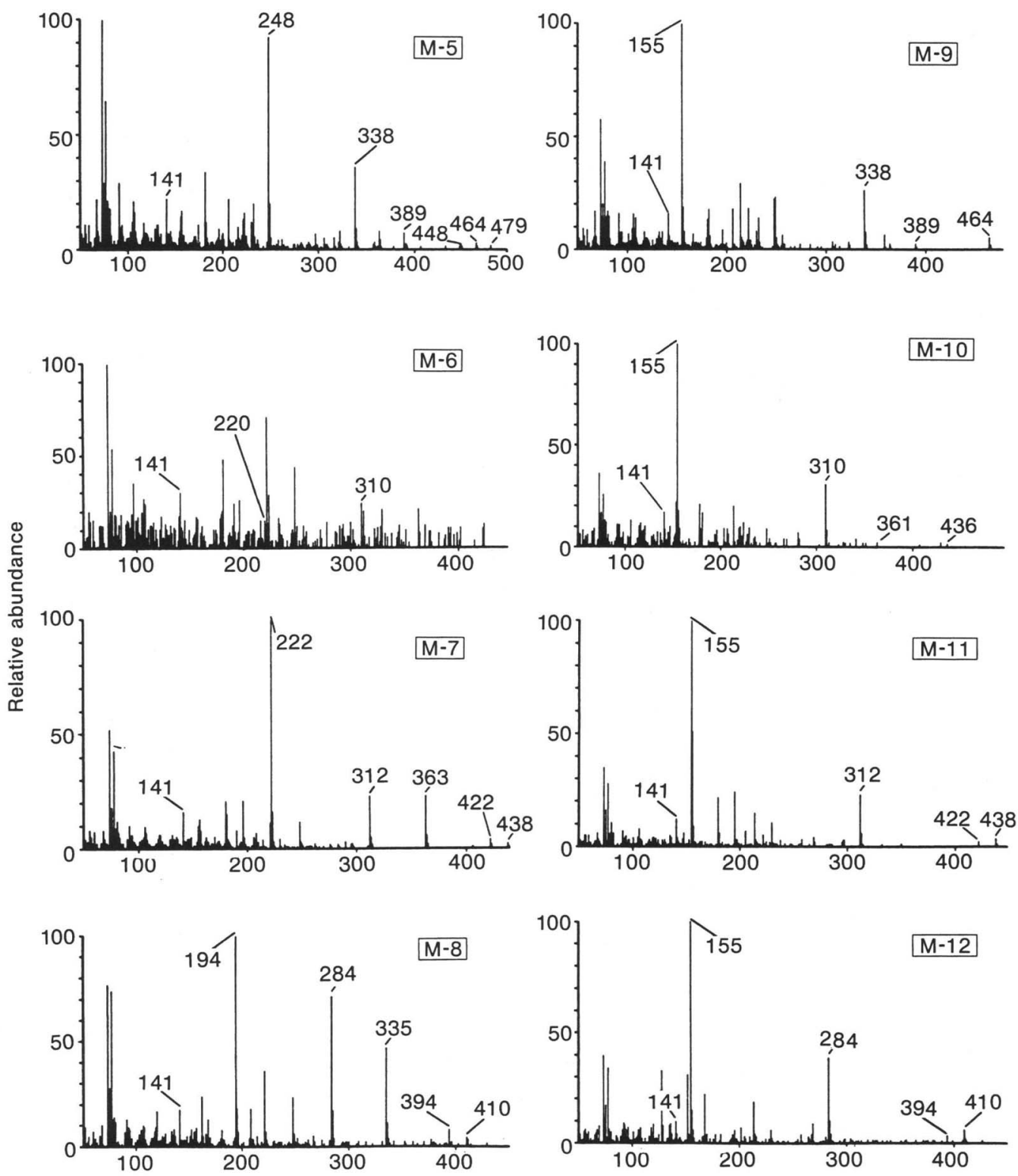

$\mathrm{m} / \mathrm{z}$

Fig. 7 EI mass spectra of the methyl ester and trimethylsilyl ether derivatives of polar metabolites (M-5 M-12) isolated from rat plasma after oral administration of S-1452

血漿中より単離した高極性代謝物 M-5～M-12 の水酸基には exo と endo の 2 種の配位が考光 られる. そこで，6-OH-(+)-S-145（exo）と異 性体の 6-OH- $-\mathrm{OH}^{-}$)-S-145（endo）の 2 種類の合 成標品の GC/MS のスペクトルおよび HPLC 保持時間を比較した. GC/MS スペクトルをFig. 8 に, HPLC クロマトグラムを Fig. 9 に示す.
GC/MS のフラグメンテーションパターンは, exo 体と endo 体でほぼ一致するものの, フラ グメントイオンのピーク強度, とくに $\mathrm{m} / \mathrm{z} 206$, 232，248の強度に大きな違いが認められた，HPLC では, 保持時間が exo 体の10.55分に対し て endo 体は17.31分と著しい違いがみられた. 代謝物M-5の GC/MS によるフラグメンテー 


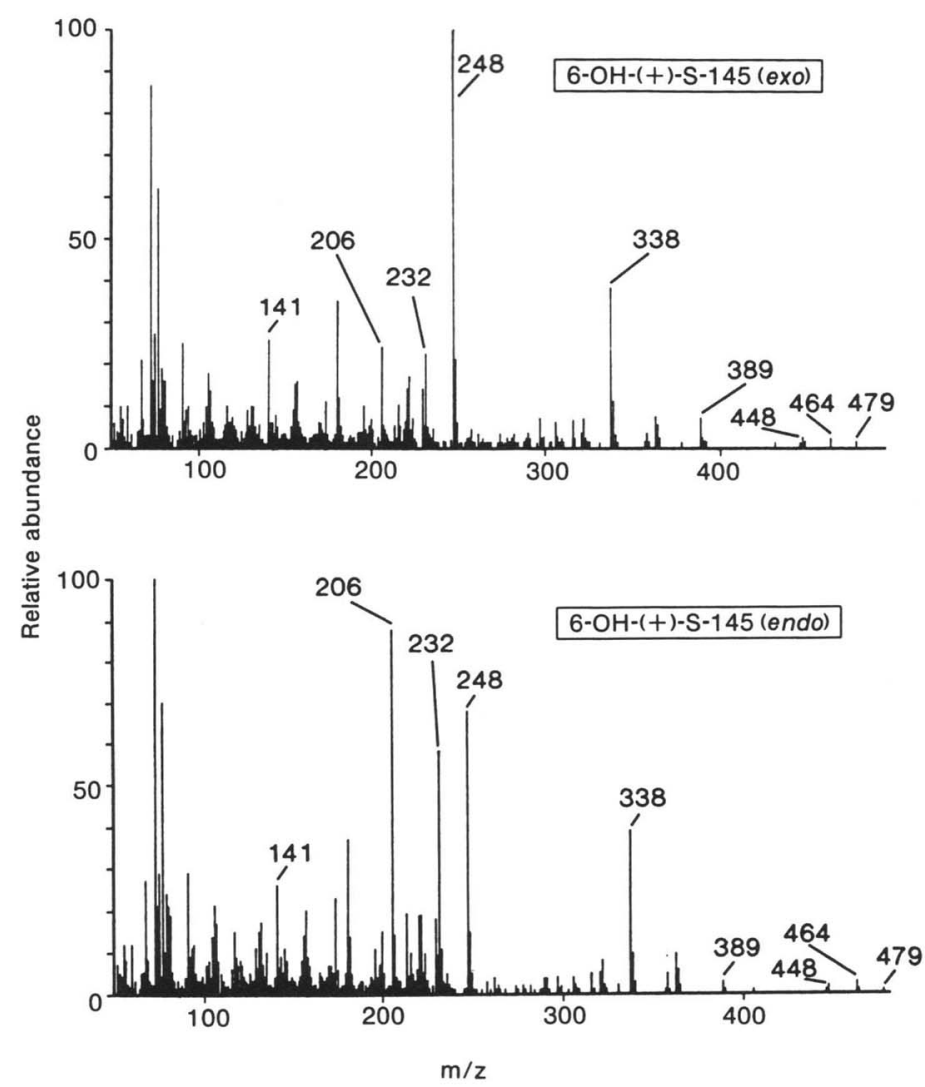

Fig. 8 EI mass spectra of the methyl ester and trimethylsilyl ether derivatives of authentic $6-\mathrm{OH}^{-}(+)-\mathrm{S}-145$ (exo) and $6-\mathrm{OH}^{-}(+)$ -S-145 (endo)

ションパターンは6-OH- $(+)-\mathrm{S}-145$ (exo) のパ ターンと等しく, HPLC 保持時間もこの条件下 では10.61分であることから， M-5の水酸基の配 位は exo 位であることが確認された. 他の高極 性代謝物の水酸基の配位も, 同定に用いた標品は すべて exo 体であり, 代謝物と標品のマススペ クトルおよび HPLC 保持時間がいずれの場合 も一致することから, すべて exo 位であること が推定された.

\section{3. 尿中代謝物の構造}

尿中より単離した $\mathrm{M}-8, \mathrm{M}-12$ の $\mathrm{GC} / \mathrm{MS}$ ス ペクトルは，それぞれ6-OH-tetranor-(+)-S145 および5- $\mathrm{OH}$ - tetranor-(+)-S-145標品の GC/MS スペクトルと完全に一致することから，
血漿中より単離したM-8, M-12 と同一代謝物で あることが確認された。尿中代謝物M-8， M-12 については，水酸基の配位を調べる目的で，さら に ${ }^{1} \mathrm{H}-\mathrm{NMR}$ 分析を行った。 スペクトルデータを Table I に示寸.

M-8ではビシクロ環 6 位 endo 配位のプロト ンシグナルが3. $64 \mathrm{ppm}$ に， 5 位の exo および endo 配位のシグナルが1.03および2.00にみられ たが, $1.3 \mathrm{ppm}$ 近傍の 6 位 exo 配位のプロトン ングナルはみられなかった。 また，M-12では, 5 位 endo 配位と 6 位の exo および endo 配 位のシグナルが $4.18,1.35$ および1.73ppm にみ られたが, $1.0 \mathrm{ppm}$ 近傍の 5 位 exo 配位のプロ トンシグナルはみられなかった。 この結果, M-8 およびM-12 とも水酸基の配位は exo 位である 


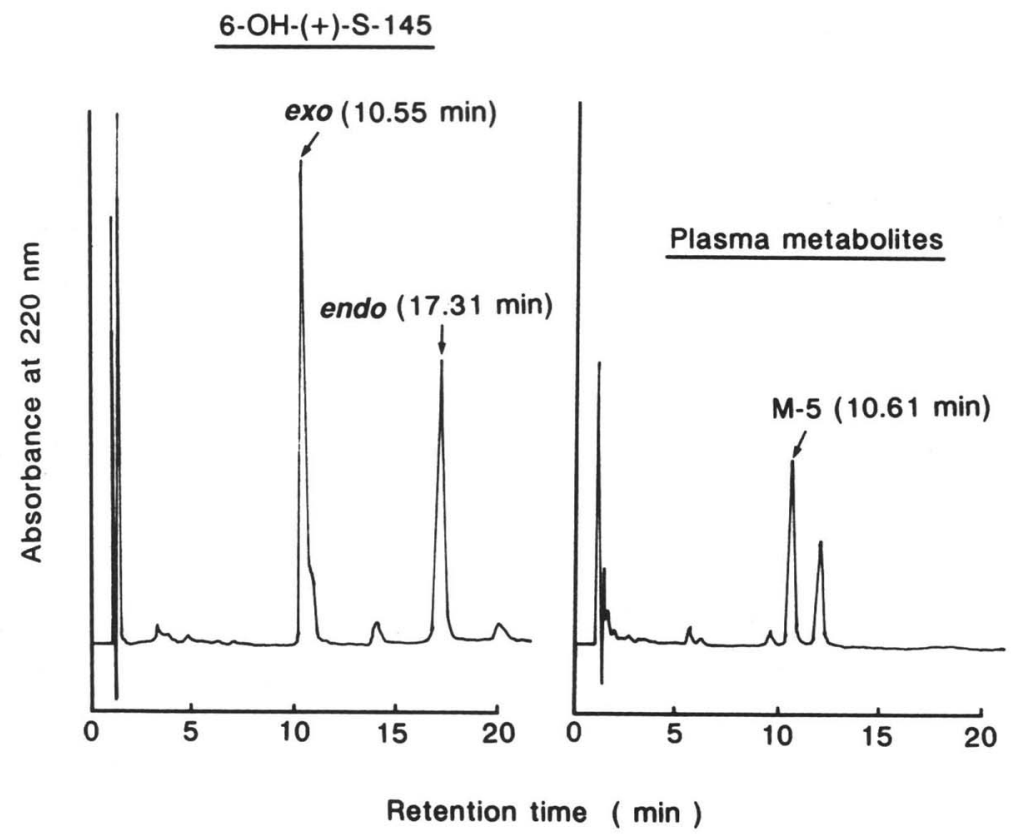

Fig. 9 High performance liquid chromatograms of authentic $6-\mathrm{OH}^{-}$ $(+)-\mathrm{S}-145$ (exo) and 6-OH-(+)-S-145 (endo) and metabolite $(\mathrm{M}-5)$ isolated from rat plasma

ことが確認され，それらの1 H-NMR スペクトル は，それぞれ6-OH-tetranor- $(+)-\mathrm{S}-145$ および 5-OH-tetranor-(+)-S-145の exo 体標品の ${ }^{1} \mathrm{H}$ -NMR スペクトルと一致した.

\section{4. 胆汁中代謝物の構造}

S-145を経口投与後 8 時間の胆汁より単離した 代謝物M-D ${ }^{1} \mathrm{H}-\mathrm{NMR}$ スペクトルでは, 3.56 $\operatorname{ppm}\left(=\mathrm{NCH}_{2}{ }^{-}\right)$および2. $95 \mathrm{ppm}\left(-\mathrm{CH}_{2}-\mathrm{SO}_{3}{ }^{-}\right)$ にタウリン抱合体の特徴的なシグナルが観察され, さらに, プロトン数および DQCOSY 測定より カップリング相関を確認した結果, M-D $\mathrm{D}$ tetranor-(+)-S-145のタウリン抱合体と推定され, 標品のスペクトルとも一致した. 次にM-A， MB， M-C抏よびM-Dのマススペクトルを測定し た. M-D，M-Cについては通常の LSIMS 測 定を行ったが，M-A和よびM-Bには夾雑物の混 入がみられたため, scanning TLC-LSIMSを 行った。 それらの特徴的なフラグメントイオンの 帰属を Table II に示す.

Table II に示す分子量領域の各イオンの帰属 結果より，M-A, M-B, M-C 抢よびM-Dの分
子量は，それぞれ484，458，456および430と決定 された.さらに，開裂イオンである $\left[\mathrm{M}-\mathrm{SO}_{2} \mathrm{Ph}\right.$ $+2 \mathrm{H}]^{+}$や $\left[\mathrm{M}-\mathrm{SO}_{2} \mathrm{Ph}\right]^{+}$あるいは $\left[\mathrm{M}-\mathrm{SO}_{2} \mathrm{Ph}\right]^{-}$ に帰属されるイオンが各代謝物で観察され, 夕 ウリンの存在を示す $\left[\mathrm{NHCH}_{2} \mathrm{CH}_{2} \mathrm{SO}_{3} \mathrm{H}\right]^{-}$, $\left[\mathrm{SO}_{3}\right]^{-}$, 拈よび $\left[\mathrm{CH}_{2} \mathrm{CONHCH}_{3}\right]^{-}$が共通し てみられた.ささらにこれらのスペクトルや HPLC の保持時間がそれぞれの予想標品と一致 することから，各代謝物は $(+)-S-145$ taurine $(\mathrm{M}-\mathrm{A})$, bisnor- $(+)-\mathrm{S}-145$ taurine $(\mathrm{M}-\mathrm{B})$, dihydrobisnor $-(+)-\mathrm{S}-145$ taurine $(\mathrm{M}-\mathrm{C})$ および tetranor- $(+)-\mathrm{S}-145$ taurine (M-D) であることが決定された。

\section{考 察}

ラットの血漿中より未变化体を含めて 12 種類, 尿中より 2 種類の第 1 相代謝物（非抱合型）を, また，胆汁中より 4 種類のタウリン抱合型代謝物 を単離同定した，尿中より単離した代謝物は，血 漿中代謝物の 2 種と一致したが，これら非抱合型 代謝物 12 種のらち 4 種は, 未変化体とその $\alpha$-鎖 の短縮型であり, 他の 8 種はビシクロ環の 5 位あ 


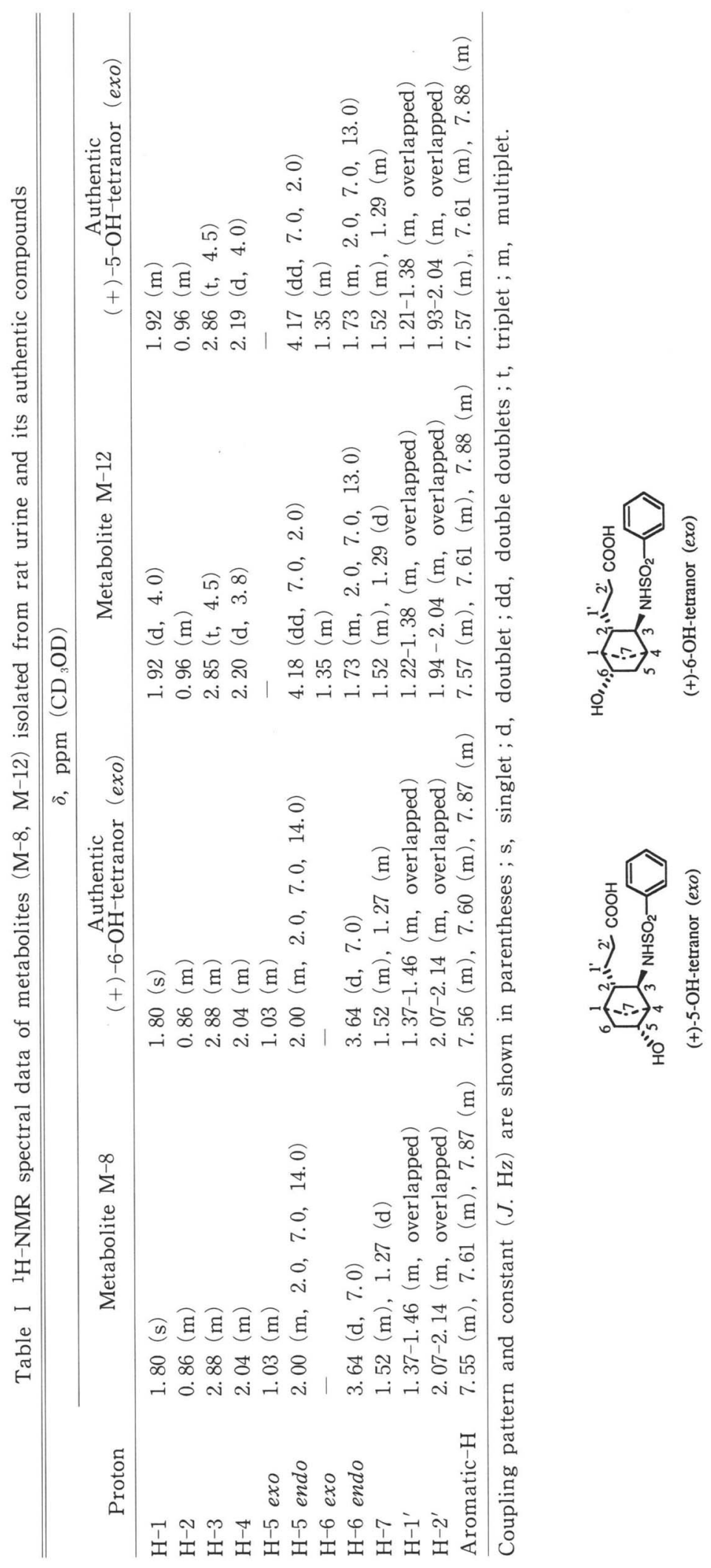


Table II LSI mass spectral data of conjugated metabolites $(\mathrm{M}-\mathrm{A} \sim \mathrm{M}-\mathrm{D})$ isolated from rat bile after oral administration of S-145

\begin{tabular}{|c|c|c|c|c|}
\hline \multirow{2}{*}{ Fragment ion } & \multicolumn{4}{|c|}{$(\mathrm{m} / \mathrm{z})$} \\
\hline & $\mathrm{M}-\mathrm{A}$ & $\mathrm{M}-\mathrm{B}$ & $\mathrm{M}-\mathrm{C}$ & $\mathrm{M}-\mathrm{D}$ \\
\hline \multicolumn{5}{|l|}{ (Positive ion) } \\
\hline$[\mathrm{M}+2 \mathrm{Na}-\mathrm{H}]^{+}$ & 529 & 501 & 503 & 475 \\
\hline$[\mathrm{M}+\mathrm{Na}]^{+}$ & 507 & 479 & 481 & 453 \\
\hline$[\mathrm{M}+\mathrm{H}]^{+}$ & 485 & 457 & 459 & 431 \\
\hline$\left[\mathrm{M}-\mathrm{NHCH}_{2} \mathrm{CH}_{2} \mathrm{SO}_{3} \mathrm{H}\right]^{+}$ & n.o. & n.o. & 334 & 306 \\
\hline$\left[\mathrm{M}-\mathrm{SO}_{2} \mathrm{Ph}+2 \mathrm{H}\right]^{+}$ & 345 & 317 & 319 & 291 \\
\hline$\left[\mathrm{M}-\mathrm{SO}_{2} \mathrm{Ph}\right]^{+}$ & 343 & 315 & 317 & 289 \\
\hline \multicolumn{5}{|l|}{ (Negative ion) } \\
\hline$[\mathrm{M}+2 \mathrm{Na}-3 \mathrm{H}]^{-}$ & n.o. & 499 & n.o. & n.o. \\
\hline$[\mathrm{M}+\mathrm{Na}-2 \mathrm{H}]^{-}$ & n.o. & 477 & 479 & 451 \\
\hline$[\mathrm{M}-\mathrm{H}]^{-}$ & 483 & 455 & 457 & 429 \\
\hline$\left[\mathrm{M}-\mathrm{SO}_{2} \mathrm{Ph}\right]^{-}$ & 343 & 315 & 317 & 289 \\
\hline$\left[\mathrm{SO}_{2} \mathrm{Ph}\right]^{-}$ & 141 & 141 & 141 & 141 \\
\hline$\left[\mathrm{NHCH}_{2} \mathrm{CH}_{2} \mathrm{SO}_{3} \mathrm{H}\right]^{-}$ & 124 & 124 & 124 & 124 \\
\hline$\left[\mathrm{SO}_{3}\right]^{-\cdot}$ & 80 & 80 & 80 & 80 \\
\hline
\end{tabular}

n.o. : Not observed.

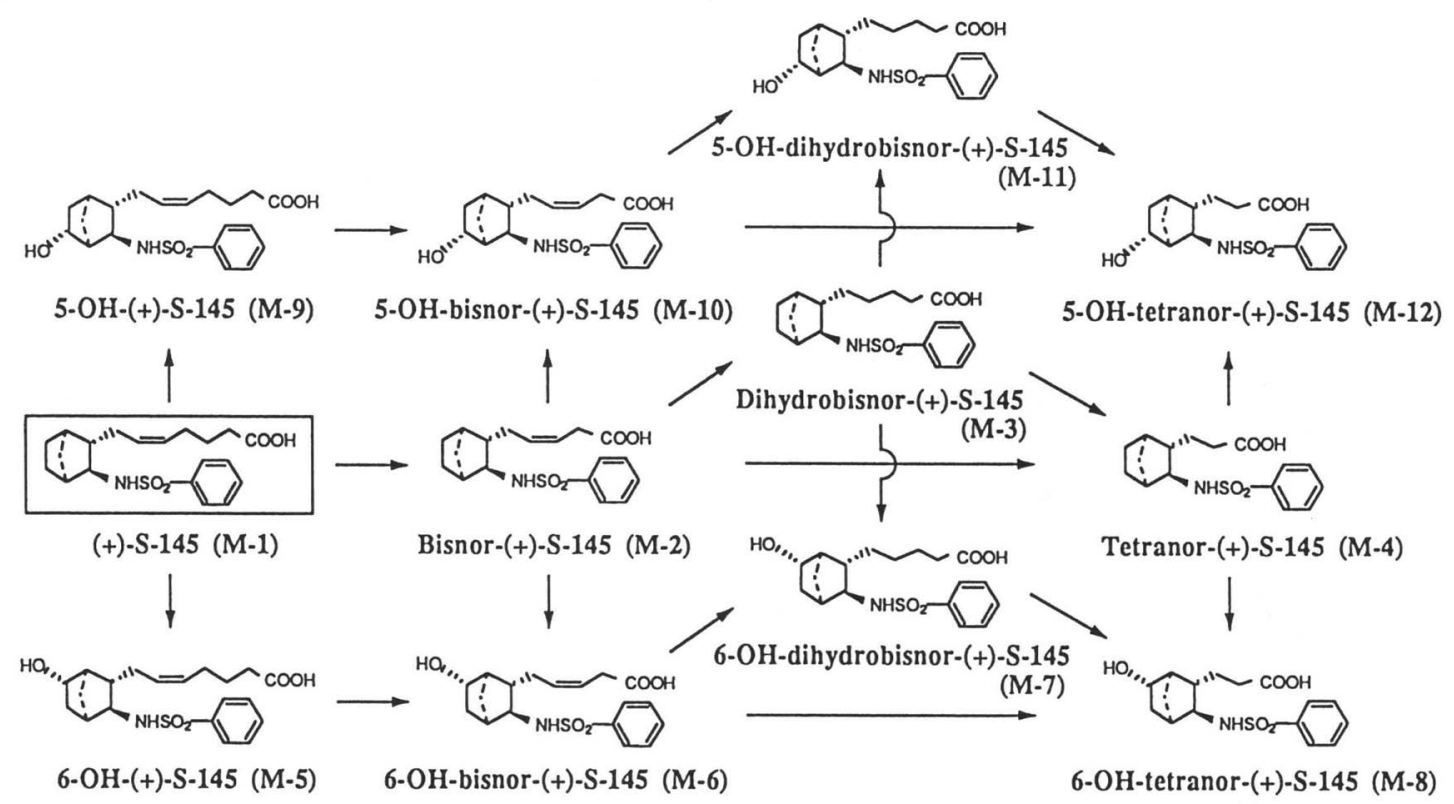

Fig. 10 Postulated metabolic pathways of (+)-S-145 in rats

るいは 6 位の水酸化体であった．非抱合型代謝物 の推定代謝経路を Fig. 10亿示す.

プロスタノイド類の $\alpha$-鎖末端が $\beta$-酸化をらけ て propionic acid 型の tetranor 体にまで短
縮化される代謝経路は，ラット10)，ヒト11 13) に おける $\mathrm{PGE}_{2}$ 類などの代謝，また，医薬品では trimoprosti1 ${ }^{14)}$, sulprostone $\mathrm{e}^{15)}$ などの代謝でみ られている. S-145では heptenoic acid 基の $\Delta^{3}$ 
二重結合が飽和された dihydrobisnor-(+)-S145が単離同定された.この種の飽和型 bisnor 体の生成は, in vitro に拈いては PGE 類をモ ルモット16) の肝ミトコンドリアとインキュベー 卜した際に認められている。一方，in vivo に打 いては, PGF 類をラット17), サルおよびヒト に18)，あるいは $\mathrm{TXB}_{2}$ をウサギ19) に投与した際 に検出されているが，比較的報告例は少ない。 た, pentenoic acid 基を持つ他の医薬品でも, trimoprostil ${ }^{14)}$ をラットに投与した際に，タウ リン抱合体として単離されている例がみられる程 度である.S-1452の開発前駆体であるS-145（ラ 七ミ体）のラット遊離肝細胞による in vitro 代 謝でも dihydrobisnor 体の生成が認められて おり，この代謝物はS-145の dihydro 体を経由 して生成されると報告されている20)。乙かし，本 研究ではラットにS-1452経口投与後の血漿ある いは尿，胆汁中に $(+)-\mathrm{S}-145$ の $\alpha$-鎖飽和型代謝 物が検出されなかったことから，in vivo に打け る dihydrobisnor 体の生成は, Fig. 10に示す ように bisnor-(+)-S-145を経由したものと考 えられる。

(+)-S-145之 $\alpha$-鎖短縮型の代謝物すべてにつ いて，ビシクロ環の 5 位あるいは 6 位が水酸化を 受けた代謝物が検出された。これら高極性代謝物 の水酸基の配位には endo, exo 位の 2 種が考え られるため, それらの 1 種であるM-5について両 配位の標品を合成し，GC/MS および HPLCの 比較によりその配位が exo 位であることを決定 した。 また，他の高極性代謝物の水酸基の配位も すべて exo 位であることが推定された. 今回, ラットより単離同定した高極性代謝物のうちのい くつかは, サルあるいはイヌの血漿中にも検出さ
れ，さらにラットおよびサル，イヌの胆汁中には 比較的多量の高極性代謝物が排泄されることか

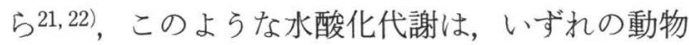
に拈いても進行して扣り，ヒトでも生成されるこ とが推測された，脂肪環の水酸化代謝で立体選択 性の高い例としては, nufenoxole の isoquinuclidine 環 5 位水酸化 ${ }^{23)}$, sparteine 94 位水酸 化 ${ }^{24)}$ の例がみられるが, S-1452の水酸化代謝に おいても，いず机の動物でも exo 体のみが生成 されることから，きわめて立体選択性の高い代謝 反応と考光られる。

S-145の $\alpha$-鎖短縮型代謝物のタウリン抱合体を 単離した. $\mathrm{PGE}_{2}$ 類薬の trimoprostil ${ }^{14)}$ では, 3 種の $\alpha$-鎖変化体とそれぞれのタウリン抱合体 が単離同定されているが，これまで，タウリン抱 合体のラットでの生成例は，2-naphthyl acetic $\operatorname{acid}^{25)}$, all-trans retinoic acid ${ }^{26)}$, pirprofen ${ }^{27}$, 3,4-dichlorobenzyloxyacetic acid ${ }^{28)}$, lovastatin 29)などでみられているが多くはない，今 回同定したタウリン抱合体はラットの胆汁から単 離したものであるが，これらの抱合体は，イヌ血 漿中およびイヌ, サルの尿, 胆汁中でも検出され ている22).ささらに，S-1452およびその代謝物のタ ウリン以外の抱合体としてグルクロナイドの生成 もラット，イヌおよびサルに执いて認められてい る21, 22).

\section{謝 辞}

標識化合物を合成していただきました当研究所 の牧角徳夫博士，濱田芳徳博士，長崎 亭，勝山 禎彦両氏ならびに代謝物標品を合成していただき ました成定昌幸博士，大谷光昭博士，渡辺文彦氏 に深謝いたします。

\section{文献}

1) Hanasaki, K. and Arita, H. : Characterization of a new compound, S-145, as a specific $\mathrm{TXA}_{2}$ receptor antagonist in platelets. Thromb. Res., 50 : 365-376 (1988).

2) Narisada, M., Ohtani, M., Watanabe, F., Uchida, K., Arita, H. and Doteuchi, M. : Synthesis and in vitro activity of various derivatives of a novel thromboxane receptor antagonist, $( \pm)-(5 Z)-7-[3-$ endo[ (phenylsulfonyl) amino]bicyclo[2.2.1]hept-2-exo-yl]heptenoic acid. J. Med. Chem., $31: 1847$ -1854 (1988).

3) Kishino, J., Hanasaki, K., Nagasaki, T. and Arita, H. : Kinetic studies on stereospecific recognition by the thromboxane $A_{2}$ /prostaglandin $\mathrm{H}_{2}$ receptor of the antagonist, S-145. Br. J. Pharmacol., 103: 1883-1888 (1991). 
4) Ohtani, M., Matsuura, T., Watanabe, F. and Narisada, M. : Enantioselective synthesis of S-1452, an orally active potent thromboxane $\mathrm{A}_{2}$ receptor antagonist. J. Org. Chem., 56:2122-2127 (1991).

5) Hanasaki, K., Nagasaki, T. and Arita, H. : Characterization of platelet thromboxane $\mathrm{A}_{2}$ /prostaglandin $\mathrm{H}_{2}$ receptor by a novel thromboxane receptor antagonist, $\left[{ }^{3} \mathrm{H}\right] \mathrm{S}-145$. Biochem. Pharmacol., 38 : 2007-2017 (1989).

6) Arimura, A., Asanuma, F., Kurosawa, A., Harada, M., Nagai, H. and Koda, A. : Pharmacologic profiles of $\mathrm{S}-1452$, a novel thromboxane $\mathrm{A}_{2}$ antagonist, as an anti-asthmatic drug. J. Allergy Clin. Immunol., 87 : 254 (1991).

7) 嘉久志寿人, 四家 勉, 早崎洋子, 有田 斉, 内田清久: 経ロトロンボキサン $\mathrm{A}_{2} /$ プ ロスタガランジンェンドペルオキシドレセプター拮抗薬, (+)-S-145カルシウム塩 二水和物の血小板凝集に対する作用. 日薬理誌, 98 : 113-120 (1991).

8) Nagasaki, T., Watanabe, F., Katsuyama, Y., Hamada, M., Ohtani, M. and Narisada, M. : Synthesis of $\left[{ }^{14} \mathrm{C}\right]$-and $\left[{ }^{3} \mathrm{H}\right]$-labelled $(+)-[1 R-[1 \alpha, 2 \alpha$ $(Z), 3 \beta, 4 \alpha]]-7-[3-[$ (phenylsulfonyl) amino $]$ bicyclo[2.2.1]hept-2-yl $]-5-$ heptenoic acid, $((+)-\mathrm{S}-145)$ and its calcium salt $(\mathrm{S}-1452)$. J. Labelled Compd. Radiopharm., $31: 23-38$ (1992).

9) Watanabe, F., Matsuura, T., Shirahase, K. and Ohtani, M. : Synthesis of metabolites of $\mathrm{S}-1452$, an orally active thromboxane $\mathrm{A}_{2}$ receptor antagonist. Chem. Pharm. Bull., 39 : 2842-2848 (1991).

10) Gréen, K. : Metabolism of prostaglandin $E_{2}$ in the rat. Biochemistry, $10: 1072-1086$ (1971).

11) Hamberg, M. and Samuelsson, B. : On the metabolism of prostaglandins $\mathrm{E}_{1}$ and $\mathrm{E}_{2}$ in Man. J. Biol. Chem., $246: 6713-6721$ (1971).

12) Steffenrud, S. : Metabolism of 16, 16-dimethyl-prostarlandin $\mathrm{E}_{2}$ in the human female. Biochem. Med., 24 : 274-292 (1980).

13) Steffenrud, S. : Metabolism of 9-deoxo-16,16-dimethyl-9-methylene prostaglandin $\mathrm{E}_{2}$ in humans. Drug Metab. Dispos., 11:255-265 (1983).

14) Kolis, S.J., Postma, E.J., Williams, T.H. and Sasso, G.J. : Identification of trimoprostil metabolites excreted in rat bile formed by oxidation and taurine conjugation. Drug Metab. Dispos., $14: 465-470$ (1986).

15) Kuhnz, W., Hoyer, G.A., Backhus, S. and Jakobs, U. : Identification of the major metabolites of the prostaglandin $\mathrm{E}_{2}$-analogue sulprostone in human plasma, and isolation from urine (in vivo) and liver perfusate (in vitro) of female guinea-pigs. Drug Metab. Dispos., 19: 920-925 (1991).

16) Steffenrud, S. : Metabolism of prostaglandin E analogs in the guinea pig liver mitochondrial fraction. Biochem. Med., 32:161-180 (1984).

17) Gréen, K. : The metabolism of prostaglandin $\mathrm{F}_{2} \alpha$ in the rat. Biochim. Biophys. Acta, 231 : 419-444 (1971).

18) Hansson, G. : Metabolism of two $\mathrm{PGF}_{2} \alpha$ analogues in primates : $15(\mathrm{~S})-15$ -methyl- $\Delta^{4}-c i s-\mathrm{PGF}_{1} \alpha$ and 16,16 -dimethyl- $\Delta^{4}-{ }^{-} i s^{-} \mathrm{PGF}_{1} \alpha$. Prostaglandins, 18 : 745-771 (1979).

19) Westlund, P., Kumlin, M., Nordenstrom, A. and Granstrom, E. : Circulating and urinary thromboxane $\mathrm{B}_{2}$ metabolites in the rabbit. Prostaglandins, $31: 413-443$ (1986).

20) Higaki, J., Tonda, K., Takahashi, S. and Hirata, M. : Metabolism of a thromboxane $\mathrm{A}_{2}$ antagonist in isolated rat hepatocytes. Biomed. Environ. Mass Spectrom., 18 : 1057-1062 (1989).

21）乗鞍 良, 吉森丈夫, 村上 剛, 中西真智子, 溝尻顕爾 : 新規トロンボキサン $\mathrm{A}_{2}$ 受 容体拮抗薬 $(\mathrm{S}-1452)$ の体内動態（第 1 報）ラットにおける ${ }^{14} \mathrm{C}-\mathrm{S}-1452$ 単回投与後 の吸収，分布，代謝抒よび排泄．薬物動態，8：83-96（1993）.

22) 乗鞍 良, 吉森丈夫, 村上 剛, 中西真智子, 溝尻顕爾 : 新規トロンボキサン $\mathrm{A}_{2}$ 受 容体拮抗薬（S-1452）の体内動態（第 4 報）イヌおよびサルに拈ける ${ }^{14} \mathrm{C}-\mathrm{S}-1452$ 投 与後の吸収, 分布, 代謝扣よび排泄. 薬物動態, 8：113-125（1993）.

23) Cook, C.S., Campion, J.G., Hribar, J.D. and Karim, A. : Metabolism and pharmacokinetics of nufenoxole in animals and humans : an example of 
stereospecific hydroxylation of an isoquinuclidine ring. Xenobiotica, 20 : 1065-1080 (1990).

24) Ebner, T., Eichelbaum, M., Fischer, P. and Meese, C.O. : Über die stereospezifische Hydroxylierung von $(+)$-Spartein (Pachycarpin) bei der Ratte. Arch. Pharm. (Weinheim), 322:399-403 (1989).

25) Emudianughe, T.S., Caldwell, J. and Smith, R.L. : Amino acid conjugation responses to 2-naphthylacetic acid in rodents. Biochem. Soc. Trans., 7 : 522-524 (1979).

26) Skare, K.L., Schnoes, H.K. and DeLuca, H.F. : Biliary metabolites of all -trans retinoic acid in the rat: isolation and identification of a novel polar metabolites. Biochemistry, $21: 3308-3317$ (1982).

27) Egger, H., Bartlett, F., Yuan, H.P. and Karliner, J. : Metabolism of pirprofen in man, monkey, rat and mouse. Drug Metab. Dispos., $10: 529-$ 536 (1982).

28) Peffer, R.C., Abraham, D.J., Zemaitis, M.A., Wong, L.K. and Alvin, J. D. : 3,4 -Dichlorobenzyloxyacetic acid is extensively metabolized to a taurine conjugate in rats. Drug Metab. Dispos., $10: 305-311$ (1987).

29) Vyas, K.P., Kari, P.H., Pitzenberger, S.M., Halpin, R.A., Ramjit, H. G., Arison, B., Murphy, J.S., Hoffman, W.F., Schwartz, M.S., Ulm, E. H. and Duggan, D.E. : Biotransformation of lovastatin 1. Structure elucidation of in vitro and in vivo metabolites in the rat and mouse. Drug Metab. Dispos., 18 : 203-211 (1990). 